Section III. Ecology and management of wild life in West Africa. (Covering wild life and vegetation, wild life and domestic animals.)

Section IV. The humid forests of West Africa, their original and present extent.

Papers are invited, and must reach the Conference Secretary before 3 I December 1958. Papers may be in either English or French, should not exceed 3,000 words, and must be prefaced by a brief summary. It is hoped to reproduce all papers for distribution during the Conference.

\title{
The African Studies Association in the United States
}

THE African Studies Association in the United States formally came into being at a conference held in New York in March 1957 (see Africa, October 1957, p. 401). During the intervening year the Board has met at intervals and reached a number of important decisions on the future policies of the Association.

The first issue of the African Studies Bulletin appeared in April 1958, and is designed to gather together some general information on the opportunities for the study of Africa in the United States and to acquaint its readers with the background of the African Studies Association. African Studies Programs of the following universities are given: Boston University; University of California at Los Angeles; Duke University Commonwealth Studies Center; Duquesne University; Hartford Seminary Foundation; School of Advanced International Studies of the Johns Hopkins University; Northwestern University; Roosevelt University; Food Research Institute of Stanford University; Yale University. It is expected that subsequent issues of the Bulletin will contain articles on topics of general interest in the field. An attempt will be made to keep the members of the Association informed of future academic visitors from Africa with their schedule of travel in the United States. News items of general interest in the field of African studies will also be included. It is planned that the Bulletin should appear quarterly in October, January, March, and May.

\section{The African Trade Development Fund}

The Government of Uganda set up the African Trade Development Fund in 1955 with the object of assisting Africans in trade, particularly in townships and major trading centres, by providing premises for rental. By this method the traders would be saved the need to invest their capital in a building and would, therefore, be able to devote it all to the speculative business of trading. At the same time Government would have a well-secured investment over which it retained full control. If a tenant failed, the investment would not suffer because the premises could be let immediately to another trader.

The scheme value of the fund is $£ 400,000$ to be received in annual instalments of which three have been paid so far to a total of $£_{17} 1,000$. The first phase of expenditure has been upon premises in the main townships. There are two reasons for this: (I) to encourage the integration of Africans and non-Africans in trade, and so help to dispel the idea held by many Africans that trading in townships was restricted to non-Africans; (ii) because capital assistance in respect of buildings is most needed in the townships where a premium has to be paid for a plot and buildings must be of a relatively high standard and value.

\section{Studia Universitatis 'Lovanium'}

THE Lovanium University at Leopoldville has, since 1957 , been publishing a series of scientific works under the title of Studia Universitatis 'Lovanium'. The series includes two 
sections at the present time-Faculty of Philosophy and Letters and Faculty of Science. Among the publications of the latter are Grammaire du Lomongo by A. de Rop (to be published May 1958) and Tenure foncière des peuples congolais (to be published July-August 1958). Letters and applications for subscriptions, purchases, and exchanges should be addressed to the Lovanium University Press, P.O.B. 23 r, Léopoldville XI (Belgian Congo).

\section{Note sur les travaux de la Mission sociologique du Haut-Oubangui}

LA mission ouvrit ses travaux en juillet 1954, à la demande du Haut-Commissariat de I'A.E.F. Une première campagne se termina au printemps I955. Une deuxième campagne a débuté en novembre 1957 et se poursuit actuellement. Eric de Dampierre est chargé de recherches, avec Pierre Clément et Jean-Marie Singa (campagne 1954-5), Dr. Anne Laurentin et Robert Bangbanzi (campagne 1957-8). Le secrétariat de la mission est assuré par une vacataire du C.N.R.S., Janine Maurel.

Les travaux entrepris par la mission sont les suivants :

I. Couverture, village par village, des pays de langue nzakara (districts de Bangassou, Bakouma et Ouango) en vue d'établissement de cartes linguistique, ethnique, politique, religieuse et professionnelle.

2. Examen critique et exploitation des données démographiques existantes.

3. Étude du système de parenté nzakara. Évolution des transactions matrimoniales sous l'influence des conditions de vie nouvelles.

4. Recherches sur la natalité en pays nzakara et ngbandi ainsi que sur différents problèmes connexes. Brousse et milieu urbain.

5. Recherche sur la condition de la femme en pays nzakara et ngbandi.

6. Établissement de budgets de ménage quotidiens en milieu urbanisé, sur de longues périodes.

7. Étude des structures politiques traditionnelles: chefferies et sultanats, clans et lignages. Étude sur le régime administratif de l'époque coloniale.

8. Recherches sur l'évolution économique du pays, depuis l'époque de la compagnie des sultanats jusqu'aux paysannats récents. 'Traditions culturales et droits coutumiers.

9. Recherches sur les cultes traditionnels et particulièrement sur le culte des ancêtres en pays nzakara.

Io. Enquête sur les attitudes et les aspirations des écoliers de Bangassou. Enquête sociométrique sur les élèves de l'école régionale.

II. Vocabulaire nzakara-français et grammaire sommaire nzakara.

Études rédigées et documents:

I. P. Clément: Rapport sur l'état démographique et sanitaire de la région de Bangassou. 1957.

2. E. de Dampierre: Étude critique de la documentation disponible sur les Bandia et les contrées gouvernées par eux. I955.

3. — Étude sur la dépopulation du Haut-Oubangui. 1955.

4. - Les structures traditionnelles du pays nzakara. 1957.

5. - L'évolution politique et administrative du Bas-Mbomou. r956.

6. L-L'évolution économique du Bas-Mbomou. 1956.

7. - Cartes historique ( $\left.1 / 1.000 .000^{\circ}\right)$, ethnique, linguistique, répartition de la population, des cultes, des chefferies Bandia $\left(\mathrm{r} / 200.000^{\mathrm{e}}\right)$. 1956 .

8. - Vocabulaire nzakara-français, sur fiches. 